\title{
Profil Penggunaan Antibiotik Pada Pasien Demam Tifoid Di Rumah Sakit Umum Daerah Provinsi NTB
}

\author{
Anna Pradiningsih a, 1 , Baiq Leny Nopitasari ${ }^{b} 2^{\star}$, Monita Sari ${ }^{c, 3}$ \\ a,b Program Studi Sarjana Farmasi, Universitas Muhammadiyah Mataram, Mataram, Indonesia, \\ ${ }^{c}$ Program Studi Diploma Tiga Farmasi, Universitas Muhammadiyah Mataram, Mataram, Indonesia, \\ 1 annapradiningsih@mail.com, ${ }^{2}$ baiqleny.nopitasari@gmail.com *
}

INFO ARTIKEL

Diterima :

17-07-2021

Disetujui :

22-07-2021

Kata kunci:

Antibiotik;

Demam Tifoid.

\section{ABSTRAK}

Demam tifoid merupakan infeksi akut pada usus halus dengan gejala demam lebih dari satu minggu, mengakibatkan gangguan pencernaan dan dapat menurunkan tingkat. Penelitian ini bertujuan untuk mengetahui profil penggunaan antibiotik pada terapi pasien demam tifoid di RSUD Provinsi NTB. Desain penelitian ini adalah observasional deskriptif, yaitu penelitian yang bertujuan untuk mendapatkan gambaran atau deskripsi tentang suatu keadaan secara objektif, Pengambilan data dilakukan secara retrospektif yaitu meneliti kebelakang dengan meneliti data skunder. Hasil penelitian menunjukkan berdasarkan distribusi jenis kelamin periode Juni 2019 adalah perempuan sebanyak I4 pasien (46\%) dan laki-laki I6 pasien (54\%) dari 30 pasien. Bedasarkan kelompok umur I2-I6 tahun dengan presentase 23\%, kedua kelompok umur 17-25 dengan presentase $16 \%$, kemudian kelompok umur 6-II tahun dengan presentase I0\% dan kelompok umur 46-55, 56-65 dan $>60$ dengan presentase 5\%. Berdasarkan peresepan antibiotik yang paling banyak diresepkan pada periode Mei - Juni 2019 adalah golongan sefalosporin sebanyak 23 resep $(76,3 \%)$ yang terdiri dari Cefixime 3 resep (10\%), Ceftriaxone 19 resep (63\%), Cefatokxim (3,3I resep\%), golongan quinolone sebanyak 6 resep (20\%) yang terdiri dari Levoploxacin 6 resep (20\%), dan Golongan klorampenicol sebanyak I resep (3,3\%). Berdasarkan bentuk sediaan, antibiotik yang paling banyak diresepkan periode Mei- juni 2019 adalah bentuk sediaan injeksi sebanyak 26 resep (81\%), bentuk sediaan sirup sebanyak 2 resep (6\%) sedangkan dalam bentuk tablet sebanyak 4 resep (I3\%).

Key word:

Antibiotic;

Typhoid fever.

\section{ABSTRACT}

Typhoid fever is an acute infection of the small intestine with symptoms of fever for more than one week, resulting in indigestion and can reduce levels. This study aims to determine the profile of the use of antibiotics in the treatment of typhoid fever patients in Mataram Province Hospital. The design of this research is descriptive observational, that is research that aims to get a picture or description of a situation objectively, data retrieval is done retrospectively by examining the backward by examining secondary data. The results showed that based on sex distribution in the June 2019 period were I 4 patients ( $46 \%$ ) and I6 patients (54\%) of 30 patients. Based on the age group of $12-16$ years with a percentage of $23 \%$, the second group of ages 17-25 with a percentage of 16\%, then the age group of 6-II years with a percentage of $10 \%$ and the age group of 46-55, 56-65 and > 60 with a percentage of $3 \%$. Based on prescription of antibiotics most prescribed from May to June 2019 are cephalosporins with 23 prescriptions $(76.3 \%)$ consisting of Cefixime 3 prescriptions (10\%), Ceftriaxone 19 prescriptions (63\%), Cefatokxim (3.3I prescription\%), quinolone group as many as 6 recipes (20\%) consisting of Levoploxacin 6 recipes $(20 \%)$, and chlorampenicol group as much as I recipe (3.3\%). Based on dosage forms, the most prescribed antibiotics in the May-June 2019 period were 26 prescription injection forms (81\%), syrup dosage 

$(13 \%)$.

This is an open access article under the CC-BY-SA license.

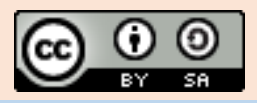

\section{Pendahuluan}

Penyakit demam tifoid merupakan infeksi akut pada usus halus dengan gejala demam lebih dari satu minggu, mengakibatkan gangguan pencernaan dan dapat menurunkan tingkat kesadaran (Rahmatillah et al., 20I4). Demam tifoid yang disebabkan oleh bakteri Salmonella typhi adalah infeksi yang terjadi secara global (Nagshetty et al., 2016). Laporan dari World Health Oerganizastion (WHO). Infeksi ini terjadi di seluruh dunia terutama di negara-negara dengan sanitasi yang buruk, WHO memperkirakan terdapat sekitar I7 juta kasus demam tifoid di seluruh dunia dengan insidensi 600.000 kasus kematian tiap tahun. Kasus terbanyak terjadi di Negara berkembang karena pertumbuhan populasi,peningkatan urbanisasi, rendahnya kebersihan air, dan sistem kesehatan (Udeze et al, 2010; Andualem et al, 20I4). Penyakit demam tifoid disebabkan oleh infeksi bakteri Salmonella typhi atau Salmonella paratyphi dan merupakan penyakit menular yang dapat menyerang banyak orang dalam waktu singkat sehingga dapat menimbulkan wabah (Garna, 2012). Masalah utama yang sering terjadi pada pasien demam tifoid antara lain adalah demam, demam sering dijumpai, biasanya demam lebih dari seminggu, pada penderita demam tifoid juga ditemui masalah mual, muntah, nyeri abdomen atau perasaan tidak enak di perut,dan diare (Nani, 20I2).

Profil kesehatan Indonesia tahun 2018 memperlihatkan bahwa gambaran I0 penyakit terbanyak pada pasien rawat inap di rumah sakit, prevalansi kasus demam tifoid sebesar 4,48\%. Penyakit ini termasuk dalam katagori penyakit dengan Case Fatality Rate tertinggi sebesar 0,57\%, demam tifoid menurut karakteristik responden tersebar merata menurut umur dan merata pada umur dewasa, akan tetapi prevarasi demam tifoid banyak ditemukan pada umur (5-19 tahun) sebesar 1,7\% dan paling rendah pada bayi sebesar $0,6 \%$. Prevalansi demam tifoid menurut tempat tinggal paling banyak dipedesaan dibandingkan dengan pendidikan rendah dan dengan jumlah pengeluaran rumah tangga rendah (Depkes RI,20I5,Profil Kesehatan Indonesia). Terdapat 800 penderita per 100.000 penduduk setiap tahun yang ditemukan sepanjang tahun. Penyakit ini tersebar diseluruh wilayah dengan insiden yang tidak berbeda jauh antara daerah. Serangan penyakit lebih bersifat sporadik dan bukan epidemik. Dalam suatu daerah terjadi kasus yang berpencar-pencar dan tidak mengelompok. Sangat jarang ditemukan beberapa kasus pada satu keluarga pada saat yang bersamaan (Widoyono,201I).

Penyaki Tropis Epidemiologi, penularan, pencegahan, dan pemberantasannya. Berdasarkan data yang diperoleh tahun 2018 Dinas Kesehatan Provinsi Nusa Tenggara Barat dalam 12 bulan terakhir, demam tifoid dapat dideteksi di Provinsi NTB dengan prevalensi I,9\% dan tersebar di seluruh kabupaten atau kota. Prevalansi demam tifoid tertinggi didapatkan di kota Bima yaitu sebesar 3,5\%. Demam tifoid terutama ditemukan pada kelompok umur usia sekolah, sedangkan jenis kelamin tidak mempengaruhi prevalensi penyakit ini. Kelompok yang berpendidikan rendah umumnya cendrung memiliki prevalensi lebih tinggi, dilihat dari aspek pekerjaan, prevalansi tertinggi demam tifoid dijumpai pada kelompok sekolah dan tidak bekerja, konsisten dengan data pada kelompok umur. Dari sudut tempat tinggal tifoid dijumpai di daerah desa dan menurut pengeluaran per kapita, tifoid lebih tinggi pada rumah tangga dengan ststus ekonomi rendah (Dinkes Provinsi NTB, 2017). Penggunaan antibiotik merupakan terapi utama pada demam tifoid, karena pada dasarnya fotogenis infeksi Salmonella typhi berhubungan dengan keadaan bakteri. Pemberian terapi demam tifoid akan mengurangi komplikasi dan angka kematian, memperpendek perjalanan penyakit serta memperbaiki gambaran klinis salah satunya dengan terjadinya penurunan demam (Depkes RI, 20I0). Namun demikian pemberian antibiotik dapat menimbulkan Drug Induce Fever, yaitu demam yang timbul bersamaan dengan pemberian terapi antibiotik dengan catatan tidak ada penyebab demam yang lain seperti adanya luka, rangsangan infeksi, trauma dan lain-lain. Demam akan hilang ketika terapi antibiotik yang digunakan tersebut diberhentikan (Hammad, 20II). 


\section{Metode}

\section{Desain Penelitian}

Desain penelitian ini adalah observasional deskriptif, yaitu penelitian yang bertujuan untuk mendapatkan gambaran atau deskripsi tentang suatu keadaan secara objektif. Pengambilan data dilakukan secara retrospektif, dimana penelitian ini akan mendiskripsikan tentang Profil penggunaan antibiotik pada pasien demam tifoid di RSUD Provinsi NTB. Pengambilan data dilakukan pada bulan Mei - Juni 2019. Sampel dalam penelitian ini adalah seluruh data pasien diagnosis demam tifoid di RSUD Provinsi NTB pada periode Mei - Juni 2019 yang memenuhi kriteria inklusi.

Kriteria Inklusi

I. Rekam medik pasien rawat inap diagnosis demam tifoid pada periode Mei - Juni 2019.

2. Resep dari pasien rawat inap diagnosis demam tifoid yang mengandung antibiotik.

Kriteria Eksklusi

I. Rekam medik dari pasien anak rawat inap diagnosis demam tifoid diluar periode Mei Juni 2019.

2. Resep dari pasien anak rawat inap diagnosisdemam tifoid yang tidak lengkap.

\section{Instrumen Penelitian}

Instrumen penelitian yang digunakan pada penelitian ini adalah data rekam medis. Data yang diambil meliputi nama pasien, jenis kelamin, dosis, bentuk sediaan dan frekuensi penggunaan.

\section{Teknik Pengumpulan Data}

Pengumpulan data dilakukan secara retrospektif yaitu meneliti kebelakang dengan meneliti data skunder.Data yang dikumpulkan merupakan data penggunaan antibiotik dari data rekam medik pasien diagnosis demam tifoid di RSUD Provinsi NTB periode Mei - Juni 2019.

\section{Hasil dan Pembahasan}

Berdasarkan hasil pengamatan data rekam medik pasien rawat inap diagnosis demam tifoid, diketahui bahwa jumlah pasien rawat inap yang didiagnosis demam tifoid di RSUD Provinsi NTB dalam rentang waktu Mei - Juni 2019 adalah 39 pasien. Dari data setiap rekam medik pasien tersebut, didapat 30 pasien rawat inap diagnosis demam tifoid yang memenuhi kriteria inklusi sebagai objek penelitian yang meliputi persentase penggunaan antibiotik, jenis kelamin, usia, lama perawatan, golongan antibiotik, dosis dan bentuk sediaan sedangkan 9 pasien rawat inap diagnosis demam tifoid yang tidak memenuhi kriteria inklusi sebagai objek penelitian dikarenakan tidak mendapatkan terapi antibiotik.

\section{Karakteristik Pasien}

I. Jenis Kelamin

Distribusi pasien demam tifoid berdasarkan jenis kelamin di RSUD Provinsi NTB periode Juni 2019 adalah perempuan sebanyak 19 pasien (5I\%) dan laki-laki 20 pasien (49\%) dari 39 pasien penderita demam tifoid. Hasil penelitian distribusi pasien berdasarkan jenis kelamin dapat dilihat pada Tabel I.

Tabel I. Karakteristik penggunaan antibiotik berdasarkan jenis kelamin

\begin{tabular}{cccc}
\hline No. & $\begin{array}{c}\text { Jenis } \\
\text { Kelamin }\end{array}$ & $\begin{array}{c}\text { Jumlah } \\
\text { Pasien }\end{array}$ & $\begin{array}{c}\text { Persentase } \\
\text { \% }\end{array}$ \\
\hline 1. & Laki - laki & 16 & 54 \\
2. & Perempuan & 14 & 46 \\
\hline & Total & $\mathbf{3 0}$ & $\mathbf{1 0 0}$ \\
\hline
\end{tabular}

Berdasarkan Tabel I dapat dilihat bahwa pasien demam tifoid berjenis kelamin perempuan 14 pasien (46\%) lebih besar daripada yang berjenis kelamin laki-laki 16 pasien (54\%). Hal ini sesuai dengan penelitian yang dilakukan di RSUD Labuan Haji Makassar tahun 2015 tentang penggunaan antibiotik pada pasien diagnosis demam tifoid yang menyebutkan bahwa diagnosis demam tifoid lebih sering terjadi pada laki-laki 56,67\% daripada perempuan 43,33\% (Novianti, 20I5). Tidak terdapat data yang menunjukkan bahwa jenis kelamin mempengaruhi angka kejadian demam tifoid. Dari banyak penelitian berpendapat pria lebih banyak menderita demam tifoid karena dipengaruhi oleh pekerjaan, kesehatan lingkungan dan kebiasaan cara makan dan minum. diketahui bahwa demam tifoid dapat menyerang setiap orang tanpa melihat jenis kelamin (Shea, et al., 20I2).

2. Umur

Distribusi umur pasien pada penelitian ini yaitu umur 0-5 tahun, 6-II tahun, I2-16 tahun, I7-25 tahun, 26-35 tahun, 36-45 tahun, 46-55 tahun, 4655 tahun dan 60 tahun. Hubungan kejadian demam tifoid pada orang dewasa karena kebiasaan jajan makanan di luar rumah, tidak mencuci tangan sebelum makan menggunakan sabun, riwayat demam tifoid dan penggunaan air bersih dalam kehidupan sehari-hari (Rakhman, 2017). Hasil penelitian distribusi pasien demam tifoid di RSUD Provinsi NTB Periode Mei - Juni tahun 2015 berdasarkan umur dapat dilihat pada Tabel 2.

Tabel 2. Karakteristik penggunaan antibiotik berdasarkan umur 


\begin{tabular}{ccc}
\hline Umur & Jumlah & Persentase (\%) \\
\hline $0-5$ & 2 & 6,7 \\
$6-11$ & 3 & 10,0 \\
$12-16$ & 7 & 23,4 \\
$17-25$ & 5 & 16.6 \\
$26-35$ & 7 & 23,4 \\
$36-45$ & 3 & 10,0 \\
$46-55$ & 1 & 3,3 \\
$56-65$ & 1 & 3,3 \\
$>60$ & 1 & 3,3 \\
\hline Total & $\mathbf{1 0 0}$ & $\mathbf{1 0 0}$ \\
\hline
\end{tabular}

Hasil penelitian pada Tabel 4 menunjukkan kelompok umur I2-I6 tahun (masa awal remaja) dan 26-35 tahun (masa dewasa awal) merupakan kelompok umur yang paling banyak mengalami demam tifoid dengan presentase 23,4 \%, kedua kelompok umur 17-25 tahun dengan presentase I6.6\%, kemudian kelompok umur 6-I I tahun dan kelompok umur 36-45 dengan presentase 10,0 \% dan terakhir kelompok umur $<46$ dengan presentase 3,3\%. Hasil penelitian di RSUD Salewangan Maros menunjukan bahwa ada hubungan antara kelompok umur dengan kejadian demam tifoid pada pasien rawat inap dimana presentase 28 penderita demam tifoid pada kelompok umur 20 - 29 tahun sebesar 23.5\% merupakan presentase terbesar dibandingkan dengan kelompok umur yang lainnya (Rustam, 20II).

3. Lama perawatan

Berdasarkan penelitian yang dilakukan terhadap profil penggunaan obat pada pasien diagnosis demam tifoid di instalasi rawat inap RSUD Provinsi NTB lama perawatan yang paling lama adalah selama 7 hari dan yang paling cepat perawatan adalah I hari, dapat dilihat pada Tabel

Tabel 3. Karakteristik penggunaan antibiotik berdasarkan lama perawatan

\begin{tabular}{|c|c|c|c|c|}
\hline No. & $\begin{array}{c}\text { Lama } \\
\text { Perawa } \\
\text { tan } \\
\text { (Hari) }\end{array}$ & $\begin{array}{c}\text { Jumla } \\
\mathbf{h} \\
\text { pasien }\end{array}$ & $\begin{array}{c}\text { Persent } \\
\text { ase } \\
(\%)\end{array}$ & $\begin{array}{c}\text { Hari } \\
x \text { Pasien }\end{array}$ \\
\hline 1 & 1 & 3 & 10,0 & 3 \\
\hline 2 & 2 & 7 & 23,4 & 14 \\
\hline 3 & 3 & 7 & 23,4 & 21 \\
\hline 4 & 4 & 3 & 10,0 & 12 \\
\hline 5 & 5 & 4 & 13,2 & 20 \\
\hline 6 & 6 & 3 & 10,0 & 18 \\
\hline 7 & 7 & 3 & 10.0 & 21 \\
\hline \multicolumn{2}{|c|}{ Total } & 30 & 100 & 109 \\
\hline \multicolumn{4}{|c|}{ Rata rata Lama Perawatan } & $\begin{array}{l}3,63 \\
\text { Hari }\end{array}$ \\
\hline
\end{tabular}

Berdasarkan karakteristik data dengan lama perawatan pada pasien diagnosis demam tifoid di instalasi rawat inap RSUD Provinsi NTB Periode Mei - Juni20I5, lama perawatan 2 dan 3 hari merupakan persentase perawatan paling banyak $(23,4 \%)$. Lama perawatan I hari merupakan lama perawatan yang paling cepat (I0,3\%) dan lama perawatan 7 hari merupakan lama perawatan yang paling lama (10,3\%). Lama perawatan 2 dan 3hari merupakan perawatan persentase paling banyak $(23,4 \%)$. Antibiotik yang digunakan selama terapi ini adalah levofloxasin dan ceftriaxone. Pada cefotaxime dosis yang diberikan I-2 gram/hari dengan maksimal penggunaan selama I0 hari sedangkan ceftriaxone dosis yang diberikan I-2 gram/hari dengan maksimal selama 7 hari (Fornas, 2015).

Lama perawatan I hari merupakan lama perawatan paling cepatLama perawatan ini paling cepat disebabkan keadaan umum pasien yang membaik dan memilih rawat jalan atau pulang sesuai permintaanorang tua pasien. Pada pasien yang memilih rawat jalan diberikan cefixime sebagai terapi pengganti. Hal ini sudah sesuai Fornas tahun 2015, pada pasien rawat inap yang sebelumnya mendapatkan antibiotik sefalosporin diberikan antibiotik dengan golongan yang sama. Lama perawatan yang cepat dikhawatirkan dapat meningkatkan resiko terjadinya komplikasi dan kekambuhan kembali (Hadisapoetro, 2015).

4. Persentase Penggunaan Antibiotik

Antibiotik yang diberikan untuk pasien demam tifoid di Instalasi Rawat Inap RSUD Provinsi NTB periode Mei - Juni tahun 2019 didapatkan dari data rekam medik berupa jenis antibiotik, dosis antibiotik, dan rute pemberian pada setiap pasien. Antibiotik yang digunakan adalah dari golongan sefalosporin generasi tiga (cefixime dan ceftriaxone), kloramfenicol (thiamphenicol) dan fluoroquinolon (levofloxacin). Antibiotik yang digunakan pada pasien demam tifoid di Instalasi Rawat Inap RSU. Provinsi NTB periode Mei- Juni tahun 2019 dapat dilihat pada Tabel 4.

Tabel 4. Karakteristik penggunaan antibiotik berdasarkan golongan antibiotik

\begin{tabular}{llcc}
\hline $\begin{array}{c}\text { Golongan } \\
\text { Antibiotik }\end{array}$ & $\begin{array}{c}\text { Jenis } \\
\text { Antibiotik }\end{array}$ & Jumlah & $\begin{array}{c}\text { Persen } \\
\text { tase }\end{array}$ \\
\hline Quinolone & Levoploxacin & 6 & 20 \\
& Cefixim & 3 & 10 \\
Sefalosorin & Ceftriaxone & 19 & 63 \\
& Cefatoxim & 1 & 3,3 \\
Kloramfen & Thiamphenicol & 1 & 3,3 \\
ocol & Jumlah & $\mathbf{3 0}$ & $\mathbf{1 0 0}$ \\
\hline
\end{tabular}

Berdasarkan Tabel 4. dapat dilihat bahwa peresepan antibiotik yang paling banyak diresepkan pada pasien diagnosisdemam tifoid di instalasi rawat inap RSUD Provinsi NTB periode Mei - Juni 2019 adalah golongan sefalosporin sebanyak 23 resep 
(76,3\%) yang terdiri dari Cefixime 3resep (10\%), Ceftriaxone 19 resep (63\%), Cefatokxim (3,3I resep\%), golongan quinolone sebanyak 6 resep (20\%) yang terdiri dari Levoploxacin 6 resep (20\%), dan Golongan klorampenicol sebanyak I resep $(3,3 \%)$. Berdasarkan hasil penelitian ini, golongan sefalosporin umumnya diberikan pada awal perawatan ketika diagnosis demam tifoid baru berdasarkan gejala klinis yang menyertai penderita karena golongan sefalosporin memiliki spektrum yang luas (Nurbaningrum, 2015). Gambaran klinis penyakit demam tifoid sangat bervariasi dari hanya sebagai penyakit ringan yang tidak terdiagnosis, sampai gambaran penyakit yang khas dengan komplikasi kematian (Depkes, 2016). Hal ini menyebabkan dokter di RSUD Provinsi NTB memberikan golongan sefalosporin pada awal perawatan. Tetapi pada penggunaan antibiotik spektrum luas secara tidak terkendali sangat memungkinkan timbulnya masalah yang tidak diinginkan seperti timbulnya efek samping obat maupun potensi terjadinya resistensi (Hadirahardja, 2018). Ceftriaxone adalah antibiotik yang sangat aktif terhadap berbagai kuman gram positif maupun gram negatif aerobik. Obat ini termasuk dalam antibiotik betalaktam, dimana memiliki mekanisme kerja menghambat sintesis dinding sel mikroba melalui reaksi transpeptidase dalam rangkaian reaksi pembentukan dinding sel (Mangunatmaja, 2013). Golongan sefalosporin inidigunakan pada infeksi yang serius seperti septikemia, pneunomia dan meningitis sebagai reserve antibiotik untuk pengobatan meningitis yang disebabkan oleh Streptococcus pneumonis pada kasus resistensi penisilin (Tambunan, et al., 2012).

Hasil penelitian Novianti tahun 2015 juga menunjukkan hasil yang sama dimana golongan sefalosporin merupakan antibiotik yang paling banyak diresepkan untuk pasien rawat inap diagnosis demam tifoid.

5. Persentase Resep yang Mengandung Antibiotik Berdasarkan Bentuk Sediaan

Berdasarkan hasil penelitian yang dilakukan terhadap profil penggunaan antibiotik pada pasien demam tifoid di instalasi rawat inap RSUD Provinsi NTB periode Mei - Juni 2019 berdasarkan bentuk sediaan dapat dilihat pada Tabel 4.5 berikut.

Tabel 5. Karakteristik penggunaan antibiotik berdasarkan umur

\begin{tabular}{cccc}
\hline No & $\begin{array}{c}\text { Bentuk } \\
\text { sediaan }\end{array}$ & Jumlah & $\begin{array}{c}\text { Persentase } \\
(\mathbf{\%})\end{array}$ \\
\hline 1 & Injeksi & 26 & 87 \\
2 & Tablet & 4 & 13 \\
\hline & Total & $\mathbf{3 0}$ & $\mathbf{1 0 0}$ \\
\hline
\end{tabular}

Berdasarkan Tabel 5. dapat dilihat bahwa bentuk sediaan antibiotik yang paling banyak diresepkan pada pasien diagnosis demam tifoid di instalasi rawat inap RSUD Provinsi NTB periode Mei- juni 2019 adalah bentuk sediaan injeksi sebanyak 26 resep (87\%), sedangkan dalam bentuk tablet sebanyak 4 resep (I3\%). Sediaan injeksi memiliki keuntungan yaitu efeknya timbul lebih cepat dan teratur dibandingkan dengan pemberian per oral, dapat diberikan pada penderita yang tidak kooperatif dan tidak sadar, serta sangat berguna dalam keadaan darurat (Surahman, et al,, 2017).

6. Keterbatasan Penelitian

Keterbatasan penelitian adalah kekurangan kekurangan peneliti dalam menyempurnakan hasil penelitiannya. Dalam penelitian ini kelemahan atau keterbatasan yang dihadapi oleh peneliti yaitu Penelitian ini hanya menggambarkan seberapa tepat dan rasional antibiotik yang diberikan kepada pasien demam tifoid tanpa menghubungkan dengan keefektifan terapi yang bisa dilihat dari lama proses penyembuhan pasien agar tergambar dengan jelas bahwa pemberian antibiotic yang rasional sangat menguntungkan bagi pasien. Salah satu dampaknya akan mempercepat proses penyembuhan.

\section{Simpulan dan Saran Kesimpulan}

Antibiotik yang paling banyak digunakan pada pasien demam tifoid di Instalasi Rawat Inap RSUD Provinsi NTB periode Mei - Juni tahun 2015 adalah ceftriaxone sebanyak 19 resep (63\%), levofloxacin sebanyak 6 resep (20\%), Cefixim sebanyak 3 resep (I0\%) kemudian cefatoxim dan thiamphenicol masing-masing sebanyak satu resep (3\%). Bentuk sediaan yangpaling banyak diresepkan adalah injeksi (87\%).

Saran

Kepada peneliti selanjutnya diharapkan dapat melakukan penelitian terkait evaluasi penggunaan antibiotik pada pasien diagnosis demam tifoid di rumah sakit lainnya agar tercapainya perbaikan tingkat rasionalitas dalam pemberian antibiotik.

\section{Daftar Pustaka}

Alam, A. (20I I). Pola Resitensi Salmonella Enterica Serotype Typhi. Departemen Ilmu Kesehatan Anak RSHS Tahun 2006 - 2010. Bandung:Sari Pediatri.

Bahn, M.K., Bahl., Bhartnagar, S. (2015). Typoid and Parathyroid Fever. Lancet: 366,749.

Bumett, C. (2015). Thypoid Fever Information. Salt Lake City: Departement Of Health Bureau of Epidemiology. 
Departemen Kesehatan, RI. (2016). Pedoman Pengendalian Demam Tifoid. Jakarta: Departemen Kesehatan Republik Indonesia.

Departemen Kesehatan, RI. (2009). Pedoman Pemantauan Terapi Obat.

Departemen Kesehatan, RI. (2013). Sistematika Pedoman Pengendalian Penyakit Demam Tifoid.Jakarta : Direktorat Jendral Pengendalian Penyakit.

Fadhilah, Khairunnisa. 2015. Profil dan Evaluasi Penggunaan Antibiotik pada Pasien Demam Tifoid di Instalasi Rawat Inap RSUP dr. Hasan Sadikin Bandung. Skripsi. Bandung. Jawa Barat.

Fransiska, M. (2012). Kerasionalan Penggunaan Antibiotik Bagian Ilmu Kesehatan Pragram Studi Farmasi. Gorontalo: Universitas Gorontalo.

Hadinegoro, SR., Tumbelaka, AR., Satari, HI. (200I). Pengobatan Cefixime Pada Demam Tifoid Anak. Sari Pediatri: I82.

Hadirahardja, M.C dan Setiawan, N. (2008). Evaluasi Penggunaan Sefotaksim Pada Pasien Anak Rawat Inap di Salah Satu Rumah Sakit Swasta Semarang bulan Oktober-Desember 2005. Yoyakarta: Universitas Gajah Mada.

Hadisaputro, S. (2015). Beberapa Faktor Yang Memberi Pengaruh Kejadian Pendarahan dan atau Perforasi Usus Pada Demam Tifoid. Jakarta: Direktorat Pembinaan Penelitian pada Masyarakat Departemen Pendidikan dan Budaya.

Hammad, O. (20II). Ceftriaxone Vs Chloramphenicol For Treatment Of Acute Typhoid Fever. Life Science Journal.

Nelwan, R. H. H. (20I2). Tata laksana terkini demam tifoid.

Widodo, J. 2006. Demam Tifoid. Dalam: Sudoyo, A.W (editor). Buku Ajar Ilmu Penyakit Dalam. Edisi keempat. Jakarta: Fakultas Kedokteran Universitas Indonesia

Novita, Yulinda. 2015. Prevalensi Demam Tifoid pada Pasien Rawat Jalan di Rumah Sakit Syarif Hidayatullah Jakarta pada Bulan Juli
Tahun 2008 sampai Juli 2009. Skripsi. Jakarta. 